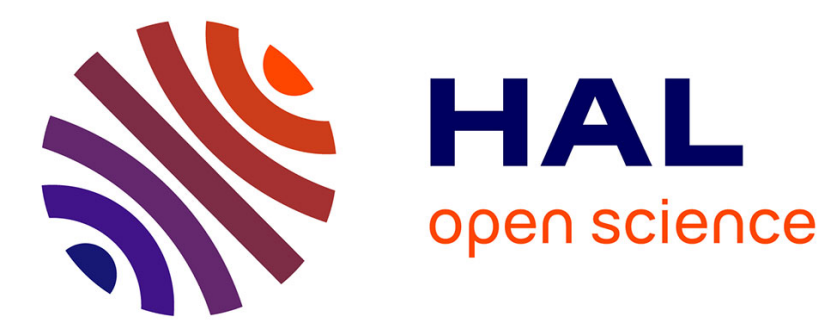

\title{
A scientific note on a genetically-determined color morph of the dwarf honey bee, Apis andreniformis
}

Jessica S. Higgs, Wandee Wattanachaiyingcharoen, Benjamin P. Oldroyd

\section{To cite this version:}

Jessica S. Higgs, Wandee Wattanachaiyingcharoen, Benjamin P. Oldroyd. A scientific note on a genetically-determined color morph of the dwarf honey bee, Apis andreniformis. Apidologie, 2009, 40 (4), 10.1051/apido/2009010 . hal-00892030

\section{HAL Id: hal-00892030 https://hal.science/hal-00892030}

Submitted on 1 Jan 2009

HAL is a multi-disciplinary open access archive for the deposit and dissemination of scientific research documents, whether they are published or not. The documents may come from teaching and research institutions in France or abroad, or from public or private research centers.
L'archive ouverte pluridisciplinaire HAL, est destinée au dépôt et à la diffusion de documents scientifiques de niveau recherche, publiés ou non, émanant des établissements d'enseignement et de recherche français ou étrangers, des laboratoires publics ou privés. 


\title{
A scientific note on a genetically-determined color morph of the dwarf honey bee, Apis andreniformis*
}

\author{
Jessica S. HigGs ${ }^{1}$, Wandee WatTANAChaiYingCharoenN ${ }^{2}$, Benjamin P. OLdROYd ${ }^{1}$ \\ ${ }^{1}$ Behaviour and Genetics of Social Insects Lab, School of Biological Sciences A12, University of Sydney, \\ NSW 2006, Australia \\ ${ }^{2}$ Department of Biology, Faculty of Science, Naresuan University, Phitsanulok 65000, Thailand
}

Received 28 October 2008 - Revised 5 February 2009 - Accepted 10 February 2009

Apis andreniformis / color morph / microsatellite

The dwarf honey bees Apis florea (Fabricius, 1787) and A. andreniformis (Smith, 1858) both build a single-comb nest from a twig in a shady location. Apis andreniformis is distributed west from the Philippines to Myanmar and China and is sympatric with A. florea in Southeast Asia (reviewed in Oldroyd and Wongsiri, 2006). Although the two species can be reliably separated by the architecture of the comb, the morphology of the endophallus and hind leg of the male, and worker wing venation (reviewed in Oldroyd and Wongsiri, 2006), variation of worker colour within the two species can lead to confusion (Hepburn et al., 2005). Typically the first two abdominal segments of an A. andreniformis worker are black and its scutellum is dark reddish brown (rufous) (Wu and Kuang, 1987). This coloration is reversed in A. florea workers which typically have rufous first and second abdominal segments, and a black scutellum. We report here on an A. andreniformis worker colour morph which is superficially similar to A. florea, and is likely controlled by a single Mendelian locus.

We captured an A. andreniformis swarm from Phitsanulok province, Thailand, $17^{\circ} 01^{\prime} \mathrm{N}$, $100^{\circ} 54^{\prime} \mathrm{E}$, in 2008 . In this swarm 55 workers were not of typical A. andreniformis colouration and we suspected that they were drifted A. florea workers. The species of these unusually-coloured workers was determined using a diagnostic length polymorphism of the mitochondrial ribosomal RNA large subunit gene (Higgs et al., unpubl. data). All bees

Corresponding author: B.P. Oldroyd,

boldroyd@bio.usyd.edu.au

* Manuscript editor: Stefan Fuchs

Online material is available at:

http://www.apidologie.org but one, which was removed before further analysis, were confirmed as A. andreniformis.

Atypical bees were examined under a dissecting microscope. The first and second segments of the abdomen were rufous and very similar to that of $A$. florea, but slightly less red. The scutellum varied from pale tan to very dark rufous (see Fig. S1 in online supplementary material). Thus the workers appeared similar to A. florea workers, especially those with a dark scutellum (Fig. S1 in online supplementary material). Unlike the typical A. andreniformis queen, which is completely black (Wu and Kuang, 1987), the queen's abdomen had four orange dorsal stripes and the ventral surface was predominately orange.

To determine if the rufous vs. black phenotype is under simple genetic control, all 54 confirmed A. andreniformis workers showing the yellow coloration (representing $3.94 \%$ of the swarm) and 70 random workers and the queen, were genotyped in a four-locus multiplex PCR reaction (Tab. I). DNA was extracted from a hind leg of each bee with Chelex (Walsh et al., 1991; Oldroyd et al., 1997) and amplified using the microsatellite primers shown in Table I. A further 31 random workers were genotyped at a single locus (Am052) that turned out to be diagnostic of the patriline showing the yellow coloration. Reactions were performed in a total volume of $5 \mu \mathrm{L}$ containing $1 \mu \mathrm{L}$ of extracted DNA.

For each worker and locus we determined which of the two alleles was the maternal allele by reference to the queen's genotype. Paternal alleles were thus unequivocally inferred by subtraction (Oldroyd et al., 1996). Fourteen patrilines were detected among the workers sampled. All 54 of the rufous colour morph workers were grouped into a single patriline. No individuals of this patriline were found 
Table I. Multiplexed loci and associated primer concentrations. All reverse primers were fluorescentlylabeled.

\begin{tabular}{lcc}
\hline Locus (Solignac et al., 2003) & No. of alleles detected & Primer concentration \\
\hline$A m 056$ & 3 & $0.34 \mu \mathrm{M}$ \\
$A m 008$ & 2 & $0.32 \mu \mathrm{M}$ \\
$A m 052$ & 3 & $0.52 \mu \mathrm{M}$ \\
$A m 061$ & 4 & $0.40 \mu \mathrm{M}$ \\
\hline
\end{tabular}

in the 101 workers with the typical black coloration. We therefore consider the rufous colour morph to be a recessive trait controlled by a single locus. In this case the queen was homozygous for the trait (as evidenced by her phenotype), and we infer that one of the males with which she mated also carried the trait.

It is unlikely that more than one male carried the allele and that progeny of this male remained undetected in the worker progeny. The probability of not detecting a patriline because two males carried the same microsatellite alleles at all four loci studied is $\prod_{i} p_{j}$, where $p_{j}$ is the frequency of the allele $j$ at the $i$ th locus. We do not have any estimate of population allele frequencies for the microsatellite loci studied, but if we make the highly conservative assumption that the only alleles in the population were those observed in the worker sample, and that each allele is at equal frequency, the non-detection rate $=0.33 \times 0.5 \times 0.33 \times 0.25=0.01$ (see Tab. I for the number of alleles detected at each locus). More importantly (for it would suggest a more complex genetic architecture to the trait) it is unlikely that we failed to detect an individual worker which was a daughter of the rufous male, but showed the normal black phenotype. For example, if under a different scenario to that which we propose, only half the workers of this patriline showed the yellow color, then the probability of not sampling one of them in a sample of size $\mathrm{n}$ is $(1-k)^{\mathrm{n}}$, where $k$ is the frequency of the patriline (in this case 0.0397) (Boomsma and Ratnieks, 1996). Thus in a sample of size 101, there was only a $1.7 \%$ chance that we would fail to detect a worker of the 'rufous' patriline should half of the individuals of that patriline be black.

The gene responsible for the unusual coloration may be that designated $F l$ by Woyke (1995), which is expressed in both queens and workers of $A$. florea and confers a similar phenotype.

\section{ACKNOWLEDGEMENTS}

Many thanks to Det and Teddy Wattanachaiyingchareon, Madeleine Beekman, James Makinson, and Sarawut Wut for their help in the field. Touchkanin Jongiitvimol took the photograph in Figure S1 in online supplementary material. This work was funded by an Australian Research Council grant to M. Beekman and B.P. Oldroyd.

Note scientifique sur un morphe de couleur à détermination génétique chez l'abeille naine, Apis andreniformis.

Zusammenfassung - Eine wissenschaftliche Notiz über eine genetisch determinierte Farbvariante der Zwerghonigbiene, Apis andreniformis.

\section{REFERENCES}

Boomsma J.J., Ratnieks F.L.W. (1996) Paternity in eusocial Hymenoptera, Philosophical Trans. R. Soc. London B 351, 947-975.

Fabricius J.C. (1787) Mantissa Insectorium Sistems eorum Species nuper Detectas adiectis Characteribus Genericus, Differentiis Specificis, Emendationibus, Observationibus, Vol. 1, C.G. Proft, Copenhagen, p. 348.

Hepburn H.R., Radloff S.E., Otis G.W., Fuchs S., Verma L.R., Ken T., Chaiyawong T., Tahmasebi G., Ebadi R., Wongsiri S. (2005) Apis florea: morphometrics, classification and biogeography, Apidologie 36, 359-376.

Oldroyd B.P., Wongsiri S. (2006) Asian Honey Bees. Biology, Conservation and Human Interactions, Harvard University Press, Cambridge, MA.

Oldroyd B.P., Clifton M.J., Wongsiri S., Rinderer T.E., Sylvester H.A., Crozier R.H. (1997) Polyandry in the genus Apis, particularly Apis andreniformis, Behav. Ecol. Sociobiol. 40, 17-26.

Oldroyd B.P., Smolenski A.J., Cornuet J.-M., Wongsiri S., Estoup A., Rinderer T.E., Crozier R.H. (1996) Levels of polyandry and intracolonial genetic relationships in Apis dorsata (Hymenoptera: Apidae), Ann. Entomol. Soc. Am. 89, 276-283.

Smith F. (1858) Catalogue of hymenopterous insects collected Sarawak, Borneo; Mount Ophir, Malacca; and at Singapore, by A.R. Wallace, Proc. Linn. Soc., Lond. 2, 42-130.

Solignac M., Vautrin D., Loiseau A., Mougel F., Baudry E., Estoup A., Garnery L., Haberl M., Cornuet J.-M. (2003) Five hundred and fifty microsatellite markers for the study of the honeybee (Apis mellifera L.) genome, Mol. Ecol. Notes 3, 307-311.

Walsh P.S., Metzger D.A., Higuchi R. (1991) Chelex (R)100 as a medium for simple extraction of DNA for PCRbased typing from forensic material, Biotechniques 10, 507.

Woyke J. (1995) Expression of body color patterns in three castes of four Asian honeybees, in: Mardan M. (Ed.), International Conference on Tropical Bees and the Environment, Pedu Lake, Malaysia, Universiti Pertanian Malaysia and SouthBound Press, pp. 85-91.

Wu Y., Kuang B. (1987) Two species of small honeybee - A study of the genus Micrapis, Bee World 68, 153-155. 